This is a post-peer-review, pre-copyedit version of an article published in 'Education and Information Technologies'. The final authenticated version is available online at: https://doi.org/10.1007/s10639017-9594-1.

\title{
"Simply the Best"1: Professors Nominated by Students for their Exemplary Technology Practices in Teaching
}

Mary Jorgensen $^{\mathrm{b}}$, Alice Havel ${ }^{\mathrm{a}, \mathrm{b}}$, Catherine Fichten ${ }^{\mathrm{a}, \mathrm{b}, \mathrm{c}, \mathrm{d}}$, Laura King ${ }^{\mathrm{b}, \mathrm{d}}$, Evelyne Marcil ${ }^{\mathrm{b}}$, Alex Lussier $^{\mathrm{d}}$, Jillian Budd ${ }^{\mathrm{b}}$, Crisitna Vitouchanskaia ${ }^{\mathrm{b}}$

${ }^{a}$ Dawson College - 3040 Sherbrooke west, Montreal, Quebec ,Canada H3Z 1A4

${ }^{b}$ Adaptech Research Network - 3040 Sherbrooke west, Montreal, Quebec, Canada H3Z 1A4

${ }^{\mathrm{c}}$ McGill University - 845 Sherbrooke Street West, Montreal, Quebec, Canada H3A 0G4

${ }^{\mathrm{d} J e w i s h}$ General Hospital - 3755 Côte-Ste-Catherine Road, Montreal, Quebec, H3T 1E2

${ }^{\mathrm{e} C e ́ g e p ~ A n d r e ́-L a u r e n d e a u ~-~ 1111, ~ r u e ~ L a p i e r r e, ~ L a s a l l e, ~ Q u e ́ b e c, ~ H 8 N ~ 2 J 4 ~}$

Corresponding author

Mary Jorgensen

3040 Sherbrooke west

Montreal QC Canada H3Z 1A4

(514) 931-8731 x3586

mjorgensen07@ubishops.ca 


\begin{abstract}
Our goal was to explore the technology related pedagogical practices of college professors deemed by their students to be excellent in using technology in their teaching. We explored the views of 114 community / junior college professors who were nominated by their students as excellent in using technology in their teaching using both questionnaires and interview methods. Results were analyzed using descriptive and inferential statistics. Results show no gender or years teaching in college differences in professors' self rated proficiency or comfort with technologies. Results also show that most professors taught themselves how to use technologies with the help of online resources, through trial and error, and with help from colleagues and support staff. Challenges using technology were related primarily to technical problems, such as technologies not working and the institution's computers and networks being slow. However, professors in our sample usually had a back-up plan and found ways to carry on even if the technology failed. Our findings report on the most and least frequently used technologies in face-to-face teaching, on how professors typically used the course management system, on how professors communicate with students, including the very small number who used social media to do this, and the likelihood of allowing students to use their personal mobile technology in class. Our findings also show that the professors showed their students how to use technologies required for the course. We discuss the practical significance of our findings and their implications for faculty, students, and the institution itself. In particular, we make recommendations about the need for ongoing collaboration between the institution, the professors, and the students and about technology related professional development professors would like to see their college provide.
\end{abstract}

Key words: excellent college professors, college teaching with technology, face-to-face, mobile technology, social media, teaching practices,

\title{
"Simply the Best"1: Professors Nominated by Students for their Exemplary Technology Practices in Teaching Introduction
}

The use of technology in class is more likely to lead to enhanced learning outcomes and student achievement when used in tandem with student-centered learning - the focus of the most recent approach to excellence in higher education teaching (Lim, Zhao, Tondeur, Chai, \& Chin-Chung, 2013). Student-centered learning emphasizes the student's role in the learning process: active engagement; emphasis on a comprehensive understanding and deep learning; student accountability and responsibility in the learning process; an increased sense of autonomy for the student; mutual respect between the professor and the student; and a reflective approach to both the teaching and learning process (Lea, Stephenson \& Troy, 2003). However, it is uncertain which pedagogical practices and technologies do, in fact, facilitate learning and student achievement (Lim, et al., 2013). One way in which student-centered learning can be adopted is to provide a combination of traditional lecture-style teaching and the use of technology in a pedagogical context (Motteram, 2005). It is, thus, primarily the professor who determines whether technology is used to promote student engagement and student-centered learning.

Even though students' and professors' views about the effectiveness of different technologies have been shown to differ (Venkatesh et al., 2016), the literature on the use of technology in teaching and learning is based primarily on data from students (Poellhuber et al., 2012; Rashid \& Asghar, 2016). Nevertheless, it is professors who set the tone and determine the pedagogical practices used in class. Of course, there are studies of faculty views about technology use in class, including its use in online learning (e.g., Croteau, Venkatesh, Beaudry, \& Rabah, 2015; Lloyd, Byrne, \& McCoy, 2012). Despite this, there are no studies on the views of professors deemed to be excellent in their use of technology. Therefore, in the present investigation we explored the views, experiences and technology-related pedagogical practices of professors deemed by students to be excellent in their use of technology in teaching in face-to-face classes.

\section{Challenges and Facilitators to Using Technology in Class}

This section addresses professors' perceived proficiency in using technology; in the literature this is typically referred to as 'their level of confidence' (Croteau et al., 2015). Here we also examine the barriers that professors encounter when using technology in class, including institutional and technical barriers.

Proficiency. The literature on professor proficiency with technology is not extensive, although there are some studies examining this construct (e.g., Croteau et al., 2015). For example, Howard and Mozejko (2015) found that professors who were more confident were more likely to use technology in their courses. The researchers did not find any significant differences between males and females in their level of confidence in their ability to use technology. 
Barriers. Reid (2014) identified a variety of barriers to the use of technology in class. One obvious barrier is unavailability of the technology. However, even when the technology is available, there are barriers that may result from the reliability and complexity of the technology. A key concern with technology that is too complex is that professors who do not feel confident in their ability to use the technology may be reluctant to try to implement it. In addition, if any technology is found to be unreliable, professors will discontinue its use (Bennett, Dawson, Bearman, Molloy, \& Boud, 2017); this may, in turn, influence others to do the same.

Another significant barrier Reid (2014) identified is lack of support from the institution. Once technology is implemented, any ongoing support is often an afterthought and, therefore, fails to take into consideration all the professors who need support and the type of support they might require. To compound this problem, the professional development training offered often does not adequately meet the needs of professors. In addition, professors do not receive much incentive for attempting to adopt new technologies, which demand more of the professors' time. Administrators may not fully understand the complexity of the technology or the time required to master the use of technology in a pedagogical context. Reid (2014) concluded that it is essential that individuals who facilitate the adoption and use of technology by professors understand the barriers that professors encounter. After having identified these barriers the individuals providing support can address the ones that are within their purview, thus working with the institution to develop best practices for faculty support.

Gebremedhin and Fenta (2015) also explored barriers that professors reported in using technology. These included professors not having enough technical knowledge; not enough technology being available; inadequate quality of computers used by students; lack of support services for technology use; as well as the absence of motivation and systems that reward professors for using technology.

\section{Pedagogical Practices}

Technologies used by professors. There is extensive literature on what technologies professors actually use. For example, Venkatesh, et al., (2016), in a large sample of 2626 professors, found that the following were frequently used: all forms of email; word processing; presentation applications such as PowerPoint and concept mapping tools; course management systems (CMS) and course web sites; internet, multimedia, CD-ROMS, DVDs; desktop publishing, video photography, scans, and screen captures; and library services, such as databases, and reference management tools.

Research in this area is often related to the use of Web 2.0 technologies, including blogs and wikis (see Croteau et al., 2015) and online tools. For example, Buchanan, Sainter and Saunders (2013) found, in a sample of 114 professors, that the 10 most frequently used technologies were: links to online library resources; online audio / video podcasts from other sources; formative online testing; online audio / video podcasts that were personally developed; the use of discussion boards for class discussions; the use of discussion boards to ask and answer frequently asked questions; blogs with the goal of encouraging reflection on learning; Wikis to facilitate collaborative learning; blogs for micropublishing; and summative online tests. In addition, recorded lectures are also increasing in popularity (O’Callaghan, Neumann, Jones, \& Creed, 2017).

Social network sites such as Twitter and Facebook have become popular in academe; yet, the empirical literature provides minimal information on faculty experiences with their use (Veletsianos \& Kimmons, 2012). However, one study reported that only eighteen percent of professors used Facebook or other social networking sites for course-related tasks even though close to $50 \%$ of professor indicated that they were open to using social network sites to a greater degree in their teaching (Caldwell, 2015). Roblyer, McDaniel, Webb, Herman and Witty (2010) found that professors are more likely than students to feel that Facebook is not a suitable tool for education. In a study of social media use at Purdue university where 126 professors who indicated using social media participated, suggest that there are several barriers to social media use; these include reliability, complexity, support, professional development, time requirements, and legal issues (Zakharov, Horton, Reid, Willis, \& Attardo, 2017).

Use of course management systems (CMS). Course management systems are ubiquitous in colleges and universities. Mott and Wiley (2009) examined the use of Blackboard by professors at Brigham Young University between 2004 and 2009. At that time, most professors used the CMS to post course material or documents. The other features of the course management system that professors used, from most to least frequently, were: posting grades online; announcements, the e-mail system associated with the CMS; assessments / quizzes; discussion forums; and virtual classrooms. More recently, in a study of 2200 professors from seven different colleges, Wilcox, Thall, and Griffin (2017) found that $96 \%$ of professors used the CMS to post course materials, $82 \%$ to communicate with students, $75 \%$ to manage grades, and $62 \%$ to post assignments, quizzes and exams. In addition, 33\% used the CMS calendar and 25\% used the CMS to manage attendance. Professors in the Wilcox et al., (2017) study were also asked which features they used the most. Professors responded as follows: $85 \%$ used the assignments feature, $80 \%$ 
the announcements, 79\% used grades and 56\% the speedgrader (a Canvas CMS feature that allows professors to view and grade submitted assignments in one place).

Use of personal mobile technologies by students. Lindroth and Bergquist (2010) state that there is no universally accepted protocol that dictates the use of mobile technologies in the classroom. Therefore, neither professors nor students fully comprehend the appropriate use of laptops and other mobile technologies in class. This culture of uncertainty has resulted in three reactions from professors: rejecting the use of laptops/mobile technologies, ignoring these, and accepting them (Kay \& Lauricella, 2011).

Some professors do not allow their students to use their laptops/mobile technologies in class at all as a result of off-task behavior (Young, 2006). This approach creates a potential confrontation between professors and the technology (Kay \& Lauricella, 2011) as well as between professors and their students, since students like it when professors let them use their personal technologies in class (Alkahtani et al., 2016).

Other professors opt to ignore laptop/mobile technology use in their classes; this leads to unstructured use where students can choose what they want to do. This approach has the inherent risk of facilitating extensive offtask behavior (Fried, 2008). However, even when they are bored, students do not necessarily use technology to engage in off-task behavior (Sharp, Hemmings, Kay, Murphy, \& Elliott, 2016). Nevertheless, studies show that using smartphones, laptops, and tablets in class frequently results in poorer learning and lower grades (Wood et al., 2011), regardless of students' intellectual ability (Ravizza, Hambrick, \& Fenn, 2014). Further, studies have shown that students who are sitting near their peers who are using their personal technologies in class are also distracted (Sana, Weston, \& Cepeda, 2013).

The third strategy, which accepts and embraces the use of laptops in class, is referred to as the structured use approach. This approach attempts to use the technology as a tool to support and enhance pedagogical practices (Gay, Stefanone, Grace-Martin, \& Hembrooke, 2001). The strategies that have been used include extensive exercises on the laptop, which are preceded by a short lecture, active use of software that is related to the course and virtual experiments which are completed in small groups (Barak, Lipson \& Lerman, 2006). Kay and Lauricella (2011) found that students engaged in more on-task behaviors, such as note-taking and other academic tasks, when professors used a structured approach to laptops in the classroom. Moreover, students spent less time on off-task behaviors, such as instant messaging and sending personal emails.

\section{Present Study}

The goal of the present descriptive study is to examine technology related experiences and practices of 114 junior / community college professors deemed by students to be excellent in their use of technology in face-to-face courses. We evaluated professors' perceived proficiency in the use of technology as well as gender differences. We also asked professors how they learned to use technology, about challenges that they encountered when using technologies in their teaching and, how they overcome these challenges. We also inquired about professors' pedagogical practices including: the technologies used in their teaching, how they used the CMS, how they communicate with students, whether or not they allow their students to use their personal technologies in class, and whether or not they show students how to use technologies needed for the course. Finally, we asked professors what technologies they wish they could use in their teaching - a 'technology wish list'.

\section{Participants}

\section{Method}

One hundred and fourteen professors from two urban junior/community colleges participated (46 females, 68 males). All were nominated by an average of 4 students as using technology in a way that worked well for them. Although this average may seem small, given that they were nominated by a sample of 311 students (Fichten, et al, 2015), there was a large pool of professors from which tour sample was nominated. Thirty-nine professors taught in Social Science, 43 in Science, and 32 in Arts programs. Approximately half of each group $(n=62)$ taught in an academic and half $(n=52)$ in a career / technical program, with the exception of Arts, (one of the colleges did not have any Arts career/technical programs). The average number of years teaching at a college was 9.33 years (median $=6.89$, range $=0$ to 38 ). The response rate of contacted professors was $87 \%$.

Measures

Measures included demographic questions, a semi-structured interview about teaching experiences with technology, a checklist of technologies used in teaching, and three Likert-scaled items evaluating proficiency and evaluating allowing students to use their personal technology in class.

Demographic questions. These included gender, years teaching at a junior / community college, discipline, and teaching in a career / technical or academic program.

Semi-structured interview. Participants were asked the following questions. 
This is a post-peer-review, pre-copyedit version of an article published in 'Education and Information Technologies'. The final authenticated version is available online at: https://doi.org/10.1007/s10639017-9594-1.

(1) What ways do you use presentation software such as Power Point, Prezi or Google Slides within your courses? (prompt: e.g., visual support, lectures, uploaded to the school's course management system)

(2) What types of computer technology do you use to teach and communicate with your students? (prompt: includes CMS, phone/email, helping them study and evaluating them, inside and outside the classroom)

(3) What challenges have you had using computer technology, and how did you overcome them? (prompt: student, teaching and institutional challenges)

(4) What helps you use computer technology effectively in your teaching? (prompt: e.g., training for professors, expert help from someone, personally owned software, personal motivation, high level of knowledge in how to use computer technology)?

(5) Is there any type of computer technology that you wish you could use in your courses? If yes, what prevents you from using these?

Responses to the questions of the semi-structured interview were coded by five coders, working in teams of two. Coding was essential for converting qualitative data into quantitative data in a reliable way so that scores could be used to calculate percentages for data analyses. Coders were trained to a minimum of $70 \%$ inter-rater agreement in accordance with a coding manual (Jorgensen, et al., 2016). The mean spot-check reliability was $86 \%$; spot-check reliabilities never fell below $70 \%$.

Checklist of Information and Communication Technology (ICT) tools used by professors in their teaching. This 37 item (Yes/No) checklist of ICT tools instructors may have used in their courses was also used in a study of students (Fichten et al., 2015). It was developed with the collaboration of team members and partner representatives.

Proficiency, Allowing Students to Use Their Personal Technology in Class. Professors completed three 6-point Likert-scaled items (1=strongly disagree, $6=$ strongly agree $)$ :

(1) I am very knowledgeable in the use of computer technologies;

(2) I am very comfortable using computer technologies; Procedure

(3) I allow my students to use computer technology in class.

The entire research protocol was approved by a recognized College Research Ethics Board. Three hundred and eleven students from a larger investigation (Fichten et al., 2015) nominated up to three professors whom they believed used ICTs well in their teaching. An attempt was made to select professors with the most nominations, while also making sure to select an equal number of professors $(n=10)$ from Social Science, Science, and Arts, as well as representing academic and career / technical programs at each of the two participating colleges. We used email to contact professors within each category from the most to least frequently nominated and e-mailed them to set up an interview. When we did not receive a response to our email, we telephoned. We contacted each professor a maximum of three times (sometimes face-to-face) or until a professor specifically told us that they were not interested in participating, whichever came earlier. Once an interview time was set we met with the professor who signed the consent form. Professors provided responses to the semi-structured interview questions and then completed the ICT checklist. This was followed by the questions related to proficiency and to allowing students to use their personal technology in class. Interviews were conducted face-to-face, and took an average of 40 minutes to complete. The interviews were not recorded, as a note-taker was used for each interview.

\section{Demographics}

\section{Results}

T-tests and chi-square tests were carried out to evaluate possible gender differences on the following: years teaching at a junior / community college, discipline, and teaching in a career / technical or academic program. There were no significant differences on any of these. Pearson correlations and descriptive statistics were used to evaluate responses to all other questions.

\section{Perceived Proficiency}

Gender. There were no significant differences between female and male professors in the degree to which they were comfortable, $t(112)=1.09, p=0.280$, or knowledgeable, $t(111)=1.52, p=0.132$ in the use of technology. The number of years that professors had taught at a junior / community college (median cut-point $=$ 6.89) was not significantly related to the professors' level of comfort with, $t(112)=1.46, p=0.146$, or knowledge of technology, $t(111)=1.51, p=0.252$. There was a significant, positive correlation between the professors' level of knowledge and comfort in the use of technology, $r(113)=0.880, p<0.001$.

\section{How Professors Learn to Use Technology / Facilitators}


As Table 1 shows, mostly professors learned to use technology on their own or they had previous experience with the technology.

\section{Challenges Encountered Using Technology}

The most common challenges were technical and institutional problems; examples are provided in Table 2 . When professors did encounter problems they dealt with the problems primarily by themselves (see Table 2).

\section{Pedagogical Practices}

Technologies most and least frequently used by professors. These data were collected from the Checklist of Information and Communication Technology (ICT). The ten technologies most frequently used by professors were, in rank order: e-mail, grades available online, assignments available online, computer labs, presentation software, web links available online, online submission of assignments, course notes / PowerPoints available online, videos, and tutorials / practice exercises available online (see Table 3 for percentages). The ten technologies least frequently used by professors were web conferencing, Twitter, chat rooms, mind mapping, podcasts, LinkedIn, clickers, blogs, Wiki sites, and Facebook (see Table 4 for percentages).

How professors use the course management system (CMS)? In addition to posting course notes/PowerPoints, the CMS was primarily used by the professors to post grades (73\%) and assignments (52\%) online. It was also used for posting attendance online (46\%), online submission of assignments (29\%), for the calendar (17\%), and for tests and quizzes online (15\%).

How Do Professors Communicate with Students?

Most professors used e-mail associated with the CMS (87\%), although some used other e-mail systems (26\%) such as Gmail, Hotmail, or a college e-mail. Some professors (25\%) also used other means to communicate with students, including instant messaging, online chats on the CMS, texting, Facebook and virtual office hours. Allowing Students to Use Their Personal Technology in Class Eighty-three percent of the professors allowed their students to use their personal technology in class. Gender and number of years teaching at a junior / community college were not significantly related to this. Do Professors Show Students How to Use Required Technologies?

Since we did not ask this question specifically, only some professors provided their views. Approximately, half of the professors (48\%) spontaneously mentioned that they showed their students how to use technology required for the course. This included showing students how to use word processing software, such as Microsoft Word, to prepare good PowerPoints presentations and use PowerPoint as an effective tool, to save files in their folders on the college system or on their USB keys, and to use the Smart Board. Only one professor said that they did not show their students how to use technology as the students were expected to know and learn how to use the technology themselves. Significantly more professors who taught in career / technical programs $(60 \%)$ showed their students how to use technology than professors who taught in academic programs $(39 \%), X^{2}(114)=15.82, p=$ 0.001 .

\section{Technology Wish List}

Not all professors said that they wanted additional technology. However, there were two technologies that professors desired, but did not yet have: clickers / polling programs and Smart Boards to make their class more interactive. Most wish list items could not be categorized. Some examples include having more MACs at the college, keeping specific software at the college, the use of e-books and the college using a single CMS.

When asked what prevented them from access to their wish list items, the most frequently mentioned barrier was that the college could not afford the technology. Professors also mentioned lack of time as a barrier; this referred most often to not having enough time to learn how to use the technology.

Although our original question asked professors what technology they wished they could have access to for their classes, they also provided requests that were not hardware or software-related. The most frequent request made was for technology related professional development, including workshops offered by the college. Workshop related requests were quite diverse and included asking for more workshops, having workshops scheduled when the professors were not teaching, making the content of the workshops more practical and based on how the technology can actually be used effectively in class, having the college offer online tutorials, and having the college post videos to show professors how to use technology.

\section{Perceived Proficiency in the Use of Technology}

\section{Discussion}

Our findings show that female and male professors reported equal proficiency and comfort in using technology. These results are similar to those of Howard and Mozejko (2015), who also found that male and female professors had the same level of confidence in their ability to use technology. 
Although the number of years teaching at the college level may affect comfort and knowledge in the use of technology, in our sample of excellent professors this was not a factor. In other more representative samples of professors this is a variable that is worth investigating.

\section{Learning to Use Technology / Facilitators}

It is important to note that facilitators are not simply the absence of barriers, and equipping a college with technology is not enough to ensure that it will be used well in a pedagogical context (Gebremedhin \& Fenta, 2015).

Most professors taught themselves how to use technology with the help of online resources or through trial and error. Help from colleagues and support staff was also frequently mentioned.

On a more important note, professors rarely mentioned workshops offered by the college: they disliked that workshops are scheduled at inconvenient times and that the content was not practical enough. The professors also said that some of the workshops offered were very basic, so the professors considered them a waste of time if they already knew how to use the basic features of the technology or if their goal was to master the more complex features of the technology. Similar to our findings, Reid (2014) also reported that opportunities for ICT related professional development often do not meet the professors' needs.

\section{Challenges Using Technology}

Some of the challenges professors in our study reported are similar to those mentioned by Reid (2014) and Gebremedhin and Fenta (2015). Technical problems, such as technology not working, was the most frequently reported barrier reported by the professors in our study. Reid (2014), as well as Gebremedhin and Fenta (2015), noted institutional problems related to the reliability of technology, such as the unavailability of the technology and the poor quality of the computers that students are using in the college. Our research adds that institutional problems can include slow networks and problems with logins. There are also similarities between their findings and the professor-related concerns in our study, specifically the idea that professors are not sufficiently familiar with the technology. In our study professors also mentioned student-related concerns, such as students with different levels of expertise in the same class and inappropriate student use of technology in class.

Overcoming challenges. When asked about how they coped with the challenges, the professors in our sample had a back-up plan and found ways to carry on in class even if the technology failed. Professors also contacted IT support services or simply stopped using the technology that was problematic or was too complex.

Asking excellent professors about how to overcome challenges provides important information and future research should further explore this topic. Findings could be informative for IT specialists and for administrators who are purchasing technologies. For example, if numerous professors stop using the same technology because it is problematic or too complex, administrators may reconsider renewing the license or purchasing the technology.

\section{Pedagogical Practices}

This section discusses many different aspects of pedagogical practices. We compare the technologies that our sample of professors used in their teaching and examine similarities and discrepancies with previous studies. We are also report on how the professors used the CMS and how they communicated with their students, including communication through social networking sites such as Facebook. We also examine the contentious question of whether or not these exemplary professors allowed their students to use their personal technology in class and noted some issues that require further research in this area. Finally, we examine whether professors showed students how to use specific technology / software required for the course.

Technologies used in teaching. The ten most frequently mentioned technologies in our study were: e-mail, grades available online, assignments available online, computer labs, presentation software, web links online, online submission of assignments, course notes / PowerPoints available online, videos, and tutorials / practice exercises available online. The least frequently used technologies were web conferencing, Twitter, chat rooms, mind mapping, podcasts, LinkedIn, clickers, blogs, Wiki sites, and Facebook. These lists do not match listings by others (e.g., Buchanan, Sainter, \& Saunders, 2013; Venkatesh et al., 2016), mainly because other studies listed different technologies and because technologies were categorized differently. For example, Venkatesh et al., (2016) listed course management systems as one category; in our study individual features of course management systems were examined, such as grades posted online, course notes available online and online submission of assignments.

How professors use the course management system. The CMS in our investigation was primarily used by the professors to post grades and assignments online. To a lesser extent it was also used for online submission of assignments, for the calendar, tests and quizzes online, as well as for attendance online. The CMS was also used to post course notes / PowerPoints online. Among professors who used PowerPoint presentations as class notes, about half posted these on the CMS: some before and some after the class. 
Some of the features of the CMS that professors in our study used are similar to those of Mott and Wiley (2009) and Wilcox et al., (2017). For example, professors in previous investigations as well as in our study used the CMS to post grades online. In addition, Mott and Wiley (2009) reported that professors used the CMS to post course materials / documents - these correspond to our posting assignments and posting course notes and PowerPoints online. One feature that professors in our investigation reported that was not mentioned in the Mott and Wiley study is the online submission of assignments. Perhaps professors and students have become more sophisticated computer users since 2009; thus online submission may be less daunting for them. As in our study, Wilcox et al. (2017) found that the CMS was used to post assignments, take attendance online, and use the calendar. One feature of the CMS mentioned by Wilcox et al. that was not mentioned by the professors in our study were announcements.

Technology professors use to communicate with students. Most of the professors in our sample used an email system, either one associated with the CMS, as in the Mott and Wiley (2009) study, or some other e-mail system. However, a small percentage of professors used Facebook to communicate with students. That only a small percentage of professors in our study used Facebook is consistent with results reported by Caldwell (2015), who also found that fewer than $20 \%$ of professors used Facebook or other social network sites for course-related tasks.

The use of personal mobile technology in class. More than $80 \%$ of the professors in our study allowed their students to use their personal technology in class. However, we did not ask the professors in what way the students were allowed to use their personal technology in class. Thus, whether they allowed students to use these to reflect a structured (Fried, 2008) or an unstructured approach (Gay, Stefanone, Grace-Martin \& Hembrooke, 2001) cannot be determined. Future research on exemplary professors should explore this issue further and inquire about whether professors place limitations on how students can use their personal technology in class - and if so, the nature of such limitations.

Do professors show students how to use technology? The need to show students how to use technologies needed for the course are not unique to junior / community college (Lai, Yeung, \& Hu, 2016). About half of our sample indicated that they showed their students how to use technologies that were required for the course. This was especially true in career / technical programs. It is important to note that professors were not only showing students how to use software specific to their course, but also showing them how to use Microsoft Word, how to prepare PowerPoint presentations and how to save files on their USB or the college system. It was unsurprising that professors in technical programs were more likely than those in academic programs to show their students how to use the required technology.

In junior / community college, it is important that professors not make the assumption that all of their students know how to use 'basic' technology that they 'should have' already learned how to use because they are "digital natives". Also, it is important that professors show students how to use technology needed to complete an assignment, such as a digital portfolio or collaborative group work online.

\section{Wish Lists}

Among technologies that professors wanted were clickers / cell-phone based polling programs and interactive whiteboards (Smart Boards) - two technologies that can make classes more interactive. The most frequently reported barrier to obtaining their wish list items concerned money: they felt that the college could not afford the technology.

Professors also mentioned the need for more time to learn to use new technologies. Consistent with the findings of Reid (2014) and Gebremedhin and Fenta (2015), professors wanted more opportunities for training. In particular, they wanted more technology-related professional development, including workshops offered by the college that are applied and practical and scheduled to fit their teaching schedules. Some professors also wanted more advanced workshops focused on the more complex features of technology.

\section{Limitations}

Our sample is not representative; first, we studied only professors who were nominated by their students for using technology well, second our sample was drawn from only two colleges. Also, we obtained only the number of years teaching at a junior / community college, not the actual age of the professors. Another limitation - or perhaps a strength - is that we used open-ended interview data for most questions.

\section{Collaboration}

\section{Practical Implications}

This section discusses the ongoing collaboration required between the institution, the professors, and the students. Specifically, the need for collaboration with college personnel to resolve problems encountered when using technology are discussed. The need for professors' collaboration with students to find out whether or not the students know how to use the technology required for the course is also discussed. 
Our findings highlight the fact that using technology in a way that works well for students is not only the professor's responsibility; rather using technology well requires an ongoing collaboration between the institution, the professors, and the students. This is demonstrated by the fact that two of the challenges encountered by professors when using technology in class were directly related to the institution and to the students.

Collaboration with the institution. To help resolve some of the institutional problems, such as the network being slow and problems with professor and student logins, those responsible for technical support at the college must first find out about the concerns of professors. While the tech support staff are likely aware of some of the difficulties, professors need to dialogue with these individuals, rather than merely "grumble" amongst themselves. After the problem is 'fixed' there should be follow-up to make sure that everything is working well. A formal feedback mechanism may facilitate the communication.

Given that the technology-related requests of professors were so diverse and because college finances are often limited, it is important to have dialogue between the professors and the institution before purchasing. Some professors may also have expertise that is invaluable as a resource in decision-making and thus identifying these individuals is important if this concern is to be effectively addressed.

Collaboration with students. Professors should not assume that students know how to use 'basic' technology, such as Microsoft Word and PowerPoint. Students may know how to use the simple features and how to complete a common task like typing, but they may not know how to use more complex features, such as track changes, formatting, and creating and editing graphs and tables. Professors who taught in career /technical programs were more aware of the need to show students how to use technology required for the class. It is important to ensure that the professors who teach in academic programs find out which technologies their students do and do not know how to use.

Similarly, to address student-related challenges, such as students overestimating their ability to use technology, professors need to find out how much students really know. The professor can facilitate this through an activity where students are asked to use software; for example, to complete a task at the beginning of the semester which requires use of the basic features of technology needed for the course. The professor must also be available and willing to help the students who do not yet have the ability to complete the 'technology test' assignment. Professors could also provide additional online support materials to help these students.

\section{Technology Related Professional Development}

This section discusses suggestions that professors have for technology related professional development provided by the college. The valuable resource that professors themselves can be is discussed, as their input is vital to maximizing the value of technology training provided by the college. Furthermore, how professors can use their peers as a valuable resource is also presented.

The barriers noted by professors demonstrate that simply equipping a college with technology is not enough to ensure that it will be used effectively in a pedagogical framework. There is also a need for more accessible training provided by the college. Given that a very small number of professors reported that they learned how to use technology through college workshops, one has to wonder why. Scheduling issues and the need for practical and applied content seem to be indicated. When it comes to planning content and scheduling of workshops, the institution should get professors' input. This could be done with a simple online questionnaire to all professors. In addition, the college can offer online tutorials or provide online resources (e.g., the ubiquitous YouTube) to show professors how to use different technologies. This would promote 'just-in-time learning,' which provides a learning solution when it is actually needed. Moreover, online videos can allow professors to pause the video, skip to different parts, and re-watch the video multiple times if needed, any time of day. Therefore, professors can learn at their own pace.

Given that professors indicated that their peers are a valued resource when learning how to use technology, the organization of communities of practices and peer mentoring could facilitate information exchange among faculty. This would be of great benefit to institutions where the resources for professional development and computer technology support may be scarce. As well, these approaches could also be implemented to address the needs of faculty in certain fields of study where they use specific technology that may not be covered in the workshops provided to the college faculty as a whole. 
This is a post-peer-review, pre-copyedit version of an article published in 'Education and Information Technologies'. The final authenticated version is available online at: https://doi.org/10.1007/s10639017-9594-1.

\section{References}

Alkahtani, M., Ahmad, A., Darmoul, S., Samman, S., Al-zabidi, A., \& Matraf, K. B. (2016). Multitasking trends and impact on education: A literature review. International Journal of Social, Behavioral, Educational, Economic, Business and Industrial Engineering, 10(3), 987-993. doi:1999.10/10004600

Barak, M., Lipson, A., \& Lerman, S. (2006). Wireless laptops as means for promoting active learning in large lecture halls. Journal of Research on Technology in Education, 38(3), 245-263. Retrieved from http://citeseerx.ist.psu.edu/viewdoc/download?doi=10.1.1.138.6601\&rep=rep1\&type=pdf

Bennett, S., Dawson, P., Bearman, M., Molloy, E. and Boud, D. (2017), How technology shapes assessment design: Findings from a study of university teachers. British Journal of Educational Technology, 48(2), 672-682. doi:10.1111/bjet.12439

Buchanan, T., Sainter, P., \& Saunders, G. (2013). Factors affecting faculty use of learning technologies: Implications for models of technology adoption. Journal of Computing in Higher Education, 25(1), 1-11. doi:10.1007/s12528-013-9066-6

Caldwell, J. M. (2015). Going where students are: Comparing faculty and student uses and perceptions of social networking in education (Doctoral dissertation). Retrieved from http://scholar.utc.edu/cgi/viewcontent.cgi?article=1293\&context=theses

Croteau, A.-M., Venkatesh, V., Beaudry, A., \& Rabah, J. (2015). The role of information and communication technologies in university students' learning experience: The instructors' perspective. Proceedings of the $48^{\text {th }}$ annual Hawaii International Conference on System Sciences, 111-120. doi:10.1109/HICSS.2015.23

Fichten, C., King, L., Jorgensen, M., Nguyen, M. N., Budd, J., Havel, A., Asuncion, J., Amsel, R., Raymond, O., \& Poldma, T. (2015). What do college students really want when it comes to their instructors' use of information and communication technologies (ICTs) in their teaching? International Journal of Learning, Teaching and Educational Research, 14(2), 173-191. Retrieved from http://ijlter.org/index.php/ijlter/article/download/522/pdf

Fried, C. B. (2008). In-class laptop use and its effects on student learning. Computers \& Education, 50(3), 906-914. doi:10.1016/j.compedu.2006.09.00

Gay, G., Stefanone, M., Grace-Martin, M., \& Hembrooke, H. (2001). The effects of wireless computing in collaborative learning environments. International Journal of Human-Computer Interaction, 13(2), 257 276. doi:10.1207/S15327590IJHC1302_10 
This is a post-peer-review, pre-copyedit version of an article published in 'Education and Information Technologies'. The final authenticated version is available online at: https://doi.org/10.1007/s10639017-9594-1.

Gebremedhin, M. A., \& Fenta, A. A. (2015). Assessing teachers' perception on integrating ICT in teaching-learning process: The case of Adwa College. Journal of Education and Practice, 6(4), 114-124. Retrieved from http://files.eric.ed.gov/fulltext/EJ1083759.pdf

Howard, S. K., \& Mozejko, A. (2015). Teachers: technology, change and resistance. In M. Henderson \& G. Romeo (Eds.), Teaching and digital technologies: Big issues and critical questions (pp. 307-317). Port Melbourne, Australia: Cambridge University Press.

Jorgensen, M., Marcil, E., Budd, J., Havel, A., King, L., \& Lussier, A. (2016). ICT and college professor interviews - Coding manual. Montreal, Quebec: Adaptech Research Network. Retrieved from http://www.adaptech.org/sites/default/files/ICT\%20and\%20College\%20Professor\%20Interviews\%20Coding\%20Manual\%20January\%207,\%202016FINAL_1.pdf

Kay, R. H., \& Lauricella, S. (2011). Unstructured vs. structured use of laptops in higher education. Journal of Information Technology Education: Innovations in Practice, 10, 33-42. Retrieved from http://www.jite.org/documents/Vol10/JITEv10IIPp033-042Kay840.pdf

Lai, C., Yeung, Y., \& Hu, J. (2016). University student and teacher perceptions of teacher roles in promoting autonomous language learning with technology outside the classroom. Computer Assisted Language Learning, 29(4), 703-723. doi:10.1080/09588221.2015.1016441

Lea, S. J., Stephenson, D., \& Troy, J. (2003). Higher education students' attitudes to student-centered learning: Beyond 'educational bulimia'? Studies in Higher Education, 28(3), 321-334. doi:10.1080/03075070309293

Lim, C. P., Zhao, Y., Tondeur, J., Chai, C. S., \& Chin-Chung, T. (2013). Bridging the gap : Technology trends and use of technology in schools. Journal of Educational Technology \& Society, 16(2), 59-68. Retrieved from http://www.ifets.info/journals/16_2/6.pdf

Lindroth, T., \& Bergquist, M. (2010). Laptopers in an educational practice: Promoting the personal learning situation. Computers \& Education, 54(2), 311-320. doi:10.1016/j.compedu.2009.07.014

Lloyd, S., Byrne, M., \& McCoy, T. (2012). Faculty-perceived barriers of online education. Journal of online learning and teaching, 8(1), 1-12. Retrieved from http://jolt.merlot.org/vol8no1/lloyd_0312.pdf

Mott, J., \& Wiley, D. (2009). Open for learning: The CMS and the open learning network. in education, 15(2). Retrieved from http://ineducation.couros.ca/index.php/ineducation/article/view/53/530

Motteram, G. (2005). Blended education and the transformation of teachers: A long-term case study in postgraduate UK higher education. British Journal of Educational Technology, 37(1), 17-30. doi:10.1111/j.14678535.2005.00511.x

O'Callaghan, F. V., Neumann, D. L., Jones, L., \& Creed, P. A. (2017). The use of lecture recordings in higher education: A review of institutional, student, and lecturer issues. Education and Information Technologies, 22(1): 399-415. doi:10.1007/s10639-015-9451-z.

Poellhuber, B., Karsenti, T., Raynaud, J., Dumouchel, G., Roy, N., Saint-Laurent, S. F., \& Géraudie, N. (2012). Les habitudes technologiques au cégep : résultats d'une enquête effectuée auprès de 30724 étudiants. Centre de recherche interuniversitaire sur la formation et la profession enseignante (CRIFPE). Note: this article was mostly written in English. Retrieved from https://eduq.info/xmlui/bitstream/handle/11515/19679/033205-poellhuber-karsenti-et-al-habitudestechnologiques-cegep-resultats-enquete-eng-2012.pdf?sequence=1\&isAllowed=y 
This is a post-peer-review, pre-copyedit version of an article published in 'Education and Information Technologies'. The final authenticated version is available online at: https://doi.org/10.1007/s10639017-9594-1.

Rashid, T., \& Asghar, H. M. (2016). Technology use, self-directed learning, student engagement and academic performance: Examining the interrelations. Computers in Human Behavior, 63, 604-612. doi:10.1016/j.chb.2016.05.084

Ravizza, S. M., Hambrick, D. Z., \& Fenn, K. M. (2014). Non-academic internet use in the classroom is negatively related to classroom learning regardless of intellectual ability. Computers \& Education, 78, 109-114. doi:10.1016/j.compedu.2014.05.007

Reid, P. (2014). Categories for barriers to adoption of instructional technologies. Education and Information Technologies, 19(2), 383-407. doi:10.1007/s10639-012-9222-z

Roblyer, M. D., McDaniel, M., Webb, M., Herman, J., \& Witty, J. V. (2010). Findings on Facebook in higher education: A comparison of college faculty and student uses and perception of social networking sites. Internet and Higher Education, 13,134-140. doi:10.1016/j.iheduc.2010.03.002

Sana, F., Weston, T., \& Cepeda, N. J. (2013). Laptop multitasking hinders classroom learning for both users and nearby peers. Computers \& Education, 62, 24-31. doi:10.1016/j.compedu.2012.10.003.

Sharp, J. G., Hemmings, B., Kay, R., Murphy, B., \& Elliott, S. (2016). Academic boredom among students in higher education: A mixed-methods exploration of characteristics, contributors and consequences. Journal of Further and Higher Education. Advance online publication. doi:10.1080/0309877X.2016.1159292

Veletsianos, G., \& Kimmons, R. (2012). Scholars and faculty members' lived experiences in online social networks. Internet and Higher Education, 16, 43-50. doi:10.1016/j.iheduc.2012.01.004

Venkatesh, V., Rabah, J., Fusaro, M., Couture, A., Varela, W., \& Alexander, K. (2016). Factors impacting university instructors' and students' perceptions of course effectiveness and technology integration in the age of web 2.0. McGill Journal of Education, 51(1), 533-562. Retrieved from http://mje.mcgill.ca/article/view/9130/7093

Wilcox, D., Thall, J., \& Griffin, O. (2017). One Canvas, two audiences: How faculty and students use a newly adopted learning management system. Proceedings of the 2016 Society for Information Technology \& Teacher Education International Conference, USA, 1163-1168. Retrieved from http://er.dut.ac.za/bitstream/handle/123456789/193/LMS\%20new\%20adopted.pdf?sequence=1\&isAllowed $=\mathrm{y}$

Wood. E., Zivcakova, L., Gentile, P., Archer, K., De Pasquale, D., \& Nosko, A. (2011). Examining the impact of off-task multi-tasking with technology on real-time classroom learning. Computers \& Education, 58(1), 365-374. doi:10.1016/j.compedu.2011.08.029

Young, J. R. (2006, June 2). The fight for classroom attention: professor vs. laptop. Chronicle of Higher Education, A27-A29.

Zakharov, W., Horton, A., Reid, P., Willis, J., \& Attardo, D. (2017). Social media: An integration guideline for teaching and learning in higher education. In F.-Q. Lai, \& J. D. Lehman (Eds.), Learning and knowledge analytics in open education (pp. 149-169). doi:10.1007/978-3-319-38956-1_12 
This is a post-peer-review, pre-copyedit version of an article published in 'Education and Information Technologies'. The final authenticated version is available online at: https://doi.org/10.1007/s10639017-9594-1. 
This is a post-peer-review, pre-copyedit version of an article published in 'Education and Information Technologies'. The final authenticated version is available online at: https://doi.org/10.1007/s10639017-9594-1.

Table 1

How Professors Learn to use Technology

\begin{tabular}{lcl}
\hline & $\%$ of professors & Examples \\
\hline Professor learns on their own & $53 \%$ & $\begin{array}{l}\text { Use online resources (e.g., videos, tutorials, websites) } \\
\text { Trial and error }\end{array}$ \\
$\begin{array}{l}\text { Previous experience with } \\
\text { technology }\end{array}$ & $43 \%$ & $\begin{array}{l}\text { Worked in computer labs } \\
\text { Worked in industry }\end{array}$ \\
$\begin{array}{l}\text { Help from colleagues, college } \\
\text { support staff }\end{array}$ & $25 \%$ & $\begin{array}{l}\text { Other faculty members } \\
\text { Tech / IT support staff at the college } \\
\text { College instructional development service } \\
\text { Community of practice }\end{array}$ \\
& $12 \%$ & $\begin{array}{l}\text { Pedagogical day workshops } \\
\text { Workshops organized by specific departments }\end{array}$ \\
Workshops offered by the college & & \\
\hline
\end{tabular}


This is a post-peer-review, pre-copyedit version of an article published in 'Education and Information Technologies'. The final authenticated version is available online at: https://doi.org/10.1007/s10639017-9594-1.

Table 2

Challenges and how they were Overcome (Solutions)

\begin{tabular}{|c|c|c|}
\hline & $\%$ of professors & Examples \\
\hline $\begin{array}{l}\text { Challenges reported } \\
\text { Technical problems }\end{array}$ & $63 \%$ & $\begin{array}{l}\text { Technology not working } \\
\text { Computers being slow } \\
\text { Files too large for the capacity of software } \\
\text { Course management systems crashing }\end{array}$ \\
\hline Institutional problems & $45 \%$ & $\begin{array}{l}\text { Network slow } \\
\text { Problems related to student and professor logins } \\
\text { Slow internet software glitches after upgrades }\end{array}$ \\
\hline Student-related concerns & $29 \%$ & $\begin{array}{l}\text { Students do not want to learn how to use technology } \\
\text { Students overestimate their ability to use technology } \\
\text { Students with different levels of knowledge of technology } \\
\text { Inappropriate use of personal technology in class }\end{array}$ \\
\hline Professor-related concerns & $21 \%$ & $\begin{array}{l}\text { Time constraints } \\
\text { Discussion forum on course management system is } \\
\text { overwhelming } \\
\text { Not being familiar enough with software }\end{array}$ \\
\hline \multicolumn{3}{|l|}{ How challenges were overcome } \\
\hline $\begin{array}{l}\text { Finding a better way to } \\
\text { cope by oneself }\end{array}$ & $42 \%$ & $\begin{array}{l}\text { Having a back-up plan } \\
\text { Printing notes or doing more group exercises in case the } \\
\text { projector fails } \\
\text { Putting files on Google Drive to overcome compatibility } \\
\text { problems between computers at home and at the college }\end{array}$ \\
\hline Calling IT support & $11 \%$ & \\
\hline $\begin{array}{l}\text { Discontinuing use of the } \\
\text { technology }\end{array}$ & $5 \%$ & \\
\hline
\end{tabular}


This is a post-peer-review, pre-copyedit version of an article published in 'Education and Information Technologies'. The final authenticated version is available online at: https://doi.org/10.1007/s10639017-9594-1.

Table 3

Ten Technologies Most Frequently Used by Professors

\begin{tabular}{lcc}
\hline & \multicolumn{2}{c}{$\begin{array}{c}\text { Professors who use the } \\
\text { technology }\end{array}$} \\
\cline { 2 - 3 } Technologies used by professors & $\mathrm{n}$ & $\%$ \\
\hline E-mail & 113 & $99 \%$ \\
Grades available online & 109 & $96 \%$ \\
Assignments available online & 107 & $94 \%$ \\
Computer labs & 104 & $91 \%$ \\
Presentation software & 104 & $91 \%$ \\
Web links available online & 103 & $90 \%$ \\
Online submission of assignments & 97 & $85 \%$ \\
Course notes / PowerPoints available online & 94 & $82 \%$ \\
Videos & 91 & $80 \%$ \\
Tutorials / practice exercises available online & 89 & $79 \%$ \\
\hline
\end{tabular}


This is a post-peer-review, pre-copyedit version of an article published in 'Education and Information Technologies'. The final authenticated version is available online at: https://doi.org/10.1007/s10639017-9594-1.

Table 4

Ten Technologies Least Frequently Used by Professors

\begin{tabular}{lcc}
\hline & \multicolumn{2}{c}{$\begin{array}{c}\text { Professors who use the } \\
\text { technology }\end{array}$} \\
\cline { 2 - 3 } Technologies used by professors & $\mathrm{n}$ & $\%$ \\
\hline Web conferencing & 9 & $8 \%$ \\
Twitter & 11 & $10 \%$ \\
Chatrooms & 12 & $11 \%$ \\
Mind Mapping & 12 & $11 \%$ \\
Podcasts & 16 & $14 \%$ \\
LinkedIn & 16 & $14 \%$ \\
Clickers & 19 & $17 \%$ \\
Blogs & 22 & $19 \%$ \\
Wiki sites & 25 & $22 \%$ \\
Facebook & 26 & $23 \%$ \\
\hline
\end{tabular}

Funding: This work was supported by the Fonds de recherche du Québec - Société et culture(FRQSC) [grant number 179119]. We would also like to thank Tehila Sacher for her help with this manuscript.

${ }^{1}$ Chapman, M., \& Knight, H. (1992). "(Simply) The Best". [Recorded by T. Turner, \& J. Barnes]. On Simply the best [CD]. Los Angeles: Capitol Records, LLC (1989). 